and the way opened to a security based on those greater and surer kinds of power which until now we have not dared to consider, much less exploit.

We are dealing with something far more profound than a difference in policy options. Our question ultimately concerns our basic conceptions of man. Is man, after all is said and done, a creature whose behavior is finally controlled through promises of physically satisfying rewards and threats of violenceinduced pain; or is he something greater, the deepest wellsprings of whose behavior contain forces responsive only to the power of love and recognition of common identity. If we deny the latter, we deny many of the core values upon which we base our claims to a preferable way of life and, indeed, our hopes for any future advance for humankind. The pacifist alternative takes these values seriously to the point of proposing them as the foundation of our defense action. The belief that all men share a common humanity which cannot be totally or permanently suppressed; the corollary that every man (including the Roman tyrant, the Buchenwald guard, the Soviet oppressor, yes, even the indifferent RAND theorist at his computer) has a "breaking point" beyond which his participation in patterned inhumanity cannot be forced; and, finally, the confidence that a disciplined, large-scale exercise of the moral power of sacrificial "love" or "soul force" will most surely bring him to that breaking point and thereby negate whatever power of violence he may have at his disposal-these deserve a far more receptive hearing than they have received on the part of those supposedly committed to the defense of the West and its Judeo-Christian foundations. If, as history has demonstrated, the way of violence demands an ever more thoroughgoing renunciation of this common humanity and its implications for our own behavior, coupled with a callous ignoring of the humanity of the "enemy," it-and not pacifism-should be rejected as a policy option not worthy of consideration. Otherwise, in the process of "defending" these most cherished values we may find ourselves forced to abandon and betray them in our total surrender to the inevitably destructive logic of violence.

\title{
correspondence
}

\section{OUR UNPRECEDENTED ETHICAL SITUATION}

Editor's note: The author of the following letter, Dr. Charles E. Silcox, was a distinguished lecturer on international affairs. His sudden death this month is a special loss to The Church Peace Union, with which he was associated for many years as its Canadian consultant on foreign policy problems.

Toronto, Ontario Sir: During the past months Worldview has presented a continually stimulating analysis of morality and foreign affairs. The several contributions of John Courtney Murray, S.J., have been especially keen. Father Murray has made sharp criticisms of what he calls "the traditional American ethic," which, he implies, is voluntarist, scriptural in a fundamentalist sense, subjectivist (a "morality of intention" in which the important element is not "what you do but why you do it"), and essentially individualistic.

This traditional American ethic, Father Murray claims, is bankrupt, and American ethical teaching is now tending toward a "situationalism" in which "the absoluteness of principle gets lost among the contingencies of fact." The system today is therefore "consciously pragmatic," and while "the old morality saw things as so simple that moral judgment was always easy, the new morality sees things as so complicated that moral judgment becomes practically impossible. The final category of moral judgment is not 'right' or "wrong' but 'ambiguous."

Much of this interpretation is probably only too true, but to such an indictment one is disposed to answer "so what?" Even if it be true, is there any alternative ethic available today more suited to meet the existing situation?

The traditional American ethic was probably based less on abstract principle than on experience. To understand the Puritan ethic-and this is, perhaps, fundamental to the understanding of America -one needs to study the Westminster Confession of Faith, especially the chapter on "The Law of God." In this the Ten Commandments, commonly called the Moral Law, are described as eternally binding, although it is at the same time stated that the ceremonial laws enunciated by Moses are "now abrogated under the new statement," and that in the same way many other "sundry judicial laws . . . ex- 
pired together with the state of that people."

Despite the high place given to the Ten Commandments, the Puritan ethic was, one suspects, empirical and modified by a general overall belief in personal responsibility. It postulated subordination to the overruling will of God, howsoever conceived and insofar as it was revealed; but the Puritan did not write "finis" or "Q.E.D." to" this conception of the will of God. In the last address of John Robinson to the Pilgrim Fathers before they embarked at Leyden for their voyage to America via England, he is reported to have said: "God has still more light to break forth from His Holy Word."

It is in some such conception of an ongoing understanding of the ethical question, and the relation of personal and social experience to the uncovering of ethical truth, that the American ethic, whether scriptural or pragmatic-or both-can claim some measure of validity despite its uncertain and untidy outlines. Indeed it is precisely when it adopts or seems an absolutist position in ethics as do the fundamentalists, or the Moral Rearmament Association, or the ultra-sentimentalists with their "What would Jesus do?"-a good enough question if anyone can answer it with complete assurance-that realistic recalcitrants are forced to take refuge in some form of ambiguism.

In the specific field of foreign policy, when doctrinaire Americans profess an ethical absolutism which they themselves frequently do not, and perhaps cannot, practice, they create resentment and distrust among their best friends and alkes. Their assertion that "all men are born free and equal" (without any precise interpretation of the egalitarianism intended); their anti-colonialism; their assumption that any group of people which claims to be a viable political unity has an inherent right to self-determination (except, perhaps, in the case of the Confederate States in 1861); their exalted devotion to the written constitution of 1787 which, with its twenty-odd amendments, is regarded not only as the new Torah but the last word in political philosophy and wisdom; their naive concept of democracy as practiced in the United States as the proper standard of true government for all nations; all these and many more policies constructed on idealistic if not absolutistic lines have created a confusion in the modern world only somewhat less upsetting than that created by the doctrinaire, absolutist regimes of Russia and China.

Those of us who live in and are proud to be citizens of "foreign" 'countries find ourselves forced, when defending certain basic American policies in international affairs, to assert repeatedly and perhaps over-hopefully: "at all events, the heart of the Amerioan people is, for the most part, in the right place."

There is something to be said for American am. biguism. A number of years ago, there was much discussion in theological circles of an "interimsethik." It was said that the early apostolic church developed its ethical theories within the framework of a faith in an imminent end of the world, and that when "the end of the world" semed to have been postponed sine die, those theories had to be revised or, at all events, freshly interpreted. Whether the theory of the "interimsethik" was overdone or not, any belief in an impending end of the world would prob. ably profoundly modify any set of values, including even what the so-called Law of Nature demanded. There seem to be hints of this in the work of St. Augustine dealing with marriage. Moral behavior has to be judged against the background of circumstance.

So, in our nuclear age, with all the uncertainties and confusions of our day-political, economic and moral-we must face situations including those in foreign policy which are unique and unprecedented. Nor is there any way in which we can solve these problems by enunciating some high-sounding generalities even about being our brother's keeper-generalities which we seek to impose on the realities of the situation even as Procrustes amputated or stretched the limbs of his captives to make them fit a particular bed. We must devise an ethic to fit the situation.

The bankruptcy of ethical theories in the West is, therefore, not primarily due to basic American weaknesses alone, however numerous these may be. It is rather due to those new features in the arising world of tomorrow to which we must adjust ourselves only with a prolonged and painful effort. Nor can we fall back upon either the Ten Commandments or the Law of Nature.

Just as Jesus, though He claimed that He had come not to destroy but to fulfill the law (the traditional ethic of His people), tried to get behind the Torah to the creative principles which lay behind its formulation and thus avoid the development of a new legalism, so we do well not to repudiate all that tradition has provided to sustain and guide us. And whatever the tradition, whether it be that of the American Puritan, however mangled by the centuries, or the older medieval tradition to which Father Murray refers, of a Law of Nature accessible through the use of Right Reason, time and circum. stances may require us to modify it as our experi- 
ence expands, and as our more exact understanding of the true laws of nature confronts us with new queries demanding new answers.

We may do well to posit some Natural Law which is or may be the ground of all our ethical thinking, the basis of whatever sense of justice we have, and which positive law seeks to approximate and incorporate in some way. But to understand in its fullness what that law is, why it is, and to set forth precisely what is its application to any specific and complex situation is probably beyond us and the limited store of right reason available to us as individuals or to us as members of a religious institution. The posture of infallibility is no longer tenable. We see through a glass darkly, and in many situations-in private life and in public policy-ambiguity is inevitable and we must fearlessly launch out into the deep, hoping for the best. But the confirmed Christian is not without confidence that whosoever seeks in all humility will find, and that when the Holy Spirit is come and visits the true believer, He will lead into all truth needful for the moment, however critical and confused the moment-may be. For the rest, the issue remains with the Eternal.

\section{Charles E. Sucox}

\section{PACIFISM AS NATIONAL POLICY}

Sir: Your February editorial states that pacifism, "clearly, cannot be advocated as a matter of national policy." I wonder by what insight this becomes so clear. Maybe you refer only to the U.S. or U.S.S.R.

Newly emerging nations in Africa might well choose such a course, for eminently sound prudential reasons. Their armies are likely in some cases to resemble comic opera masquerades. Some such armies may serve, at least temporarily, as a focus of national stability, but they can also become marauding bands that terrorize the population, as in the Congo. If their leaders get serious about it, they must mortgage their freedom in order to get sub. stantial arms from one of the adversaries in the Cold War.
In England there are those who advocate unilateral disarmament, well aware of the fact that American power would still loom behind them. Nevertheless, it is at least arguable that British security would be no less tenuous if it rested on unilateral withdrawal from the arms race and a new politico-economic peace offensive in cooperation with other "nations in between" similarly disposed. If it be claimed that this would signal progressive disengagement of Western, then Eastern, Europe, this may be true, and again it is arguable that the security of this area may thus be enhanced rather than jeopardized more than it is at present.

Japan is hesitantly moving toward rearmament, but it does not seem wise to insist a pacifist policy is irrelevant to Japan's plight. As Red China's power mounts, the American presence in Japan and related areas may prove to be a military liability. In any case the present perilous equilibrium at the truce points cannot be expected to last indefinitely. Japanese initiative in the direction of unilateral disarmament as part of a radical reorientation of policy may be the best alternative possible, rather than the eventual undermining of an untenable policy that would invite disorder with no viable base from which to build for the future.

India may one day be driven to choose between consciously returning to Gandhian non-violence or undertaking a disastrous arms race with China.

If any of these possibilities would be realized, and cooperative efforts among such nations gather momentum, such a "wedge of peace" between the two giants would precipitate a radically new situation and open the way for the emergence of new forces within the alliances and even in both the U.S. and the U.S.S.R. Then, in your words, "new directions [can be] taken, in light of the unprecedented dangers which the present direction of the world offers."

It seems to me entirely appropriate to attempt fresh conceptual approaches to the situation we confront, including the possibility of a world without war.

Charles C. Walker

Just published: THE MORAL DILEMMA OF NUCLEAR WEAPONS: ESSAYS FROM Worldview by John Courtney Murray, S. J., Julian N. Hartt, Steven S. Schwarxschild, John Cogley, Walter Millis, Stephen G. Cary, Ernest W. Lefever, John C. Bennett, Paul Ramsey and Kenneth W. Thompson.

$$
78 \text { pages }-\$ 1 \text { postpaid }- \text { Quantity rates available upon request }
$$

